\title{
Symbiotic efficiency of native rhizobia in legume tree Leucaena leucocephala derived from several soil classes of Brazilian Northeast region
}

\author{
Vinicius Santos Gomes da Silva ${ }^{1}$, Carolina Etienne de Rosália e Siva Santos ${ }^{1}$, Ana Dolores Santiago de \\ Freitas ${ }^{1}$, Newton Pereira Stamford ${ }^{1}$, Aleksandro Ferreira da Silva ${ }^{1}$, Maria do Carmo Catanho Pereira de \\ Lyra $^{2}$, Leandro Reis Costa Santos ${ }^{1}$, Juscélia da Silva Ferreira ${ }^{1}$ \\ ${ }^{1}$ Departamento de Agronomia, Universidade Federal Rural de Pernambuco. 52171-900, Recife, Pernambuco, Brazil \\ ${ }^{2}$ Instituto Agronômico de Pernambuco, 52171-900, Recife, Pernambuco, Brazil
}

*Corresponding author: vinicius.agro2008.1@gmail.com

\begin{abstract}
The effective symbiotic activity of rhizobia can contribute increment of biological nitrogen fixation (BNF), which is of great importance in low technology regions. This study aimed to evaluate the symbiotic efficiency of native rhizobia from Brazilian Northeast soils for selection of the most efficient and competitive strains for Leucaena leucocephala plant. The greenhouse test was conducted in factorial scheme (7x3), with seven fertilization treatments and three soil classes (Luvisol, Ultisol and Oxisol). The fertilization treatments were: (a) four native rhizobia isolates, obtained from nodules of L. leucocephala grown in Brazilian semiarid soils; (b) recommended strain (SEMIA 6069); (c) control without rhizobia inoculation and without N fertilization; (d) control without rhizobia, but with $\mathrm{N}$ fertilization $\left(100 \mathrm{mg} \mathrm{kg}^{-1}\right)$. The plants were harvested at 90 days and the following characteristics were determined: plant height, diameter, shoots dry matter, roots dry matter and nodules dry matter, number of nodules, nitrogen concentration and accumulation in shoots, and efficiency of nitrogen fixation. The isolates $36 \mathrm{~F}$ and $45 \mathrm{G}$ are very promising on Biologic Nitrogen Fixation (BNF). They showed high symbiotic efficiency (higher than $90 \%$ ). These selected strains provided the best characteristics such as plant height $(57$ and $52 \mathrm{~cm})$, diameter $(4.03$ and $4.02 \mathrm{~mm})$, dry matter of shoot $\left(3.2\right.$ and $\left.3.6 \mathrm{~g} \mathrm{plant}^{-1}\right)$ and nitrogen accumulation in shoots (60 and $65 \mathrm{mg}$ plant-1).
\end{abstract}

Keywords: Biological nitrogen fixation, inoculants, sustainable agriculture, strain selection, symbiosis.

Abbreviations: BNF_Biological nitrogen fixation; cfu_colony forming units; FACEPE_Fundação de Amparo à Ciência e Tecnologia do Estado de Pernambuco.

Introduction

The adequate management of biological nitrogen fixation (BNF) is an important strategy to promote the sustainability and food security in many tropical regions. In general, in semiarid regions such as those found in the Brazilian Northeast, the soils have low available N. Usually, these agricultural systems do not use mineral fertilizers and predominated $\mathrm{N}$-dependent crops are produced from the mineralization of organic matter and the BNF process (Freitas et al., 2010, Martins et al., 2015). Naturally, after successive agricultural cropping, the soil may become depleted, degraded, and finally abandoned for regenerations of the natural vegetation. In these conditions the soil restoration is necessary, especially for enrichment of nutrients, mainly nitrogen that needs a faster recovery of the vegetation (Silva et al., 2017).

In these sites, the process of BFN is the main form to supply $\mathrm{N}$ enrichment of the soil (Freitas et al., 2015). However, a viable and sustainable alternative for agricultural systems and rehabilitation of degraded areas of the semiarid region is the planting of legumes with the ability to associate symbiotically with nitrogen-fixing bacteria (Yuan et al., 2016). These legumes can be used in the agroforestry systems, mainly in the soils with low nitrogen content, to produce high quality forage for animal feed, wood and firewood, live fences, shade trees for planting crops and green manure (Freitas et al., 2011; Estringana et al., 2013; Martins et al., 2015).

The success for introduction of tree legumes in the semiarid region depends on the presence and extent of native rhizobia that have ability to establish more effective symbiosis due to the soil and local adaptation (Silva et al., 2016). The tree legume $L$. leucocephala can associate with a wide range of native rhizobia strains. In these areas effective nodulation is generally observed. In some cases the nodules formation are occurred but the symbiosis may be not effective (Faye et al., 2007, Silva et al., 2017). The contribution of natural fixed $\mathrm{N}$ due to symbiosis with native rhizobia has revealed varied rates of fixation in tree legumes, demonstrating the variability in the efficiency of indigenous rhizobia. This fact evidences the need of specific researches to study the process of effective inoculation and to observe the competitive behavior or the native strains to optimize the process (Souza et al., 2012; Silva et al., 2017). 
In recent studies, selection of effectiveness and competitiveness of rhizobia have been carried out in several herbaceous legumes in Brazilian semiarid soils, especially peanut (Sizenando et al., 2016), lima bean (Antunes et al., 2011) and cowpea (Xavier et al., 2017). However, few studies were conducted to evaluate the effectiveness of native isolates in nodulation of tree legume (Erythrina velutina Willd.) (Menezes et al., 2017).

Thus, the objective of this study was to evaluate the symbiotic efficiency of native rhizobia from the Brazilian Semiarid region for inoculation of Leucaena leucocephala (Lam.) grown in different soil types.

\section{Results}

\section{Height and shoot diameter of Leucaena leucocephala}

The seedlings of $L$. leucocephala were developed normally and the survival rate was $100 \%$ under all treatments. At 30 days after sowing, the seedlings presented uniformity and no differences were observed among treatments. The mean height of plant recorded as $14.9 \mathrm{~cm}$ (Table 3). At this stage, the height varied from 14.1 to $15.7 \mathrm{~cm}$. At 60 days after sowing, the L. leucocephala presented an average height of $28.2 \mathrm{~cm}$. Also, no significant difference of rhizobia inoculation was observed. However, at 90 days, influence of rhizobia inoculation was observed. The higher height with the isolates $36 \mathrm{~F}$ and $45 \mathrm{G}$, presented growth of 57 and $52 \mathrm{~cm}$ that were higher than absolute control and mineral $\mathrm{N}$ control (Table 1).

Regarding the shoot diameter, all treatments were similar at 30 days of sowing, with a mean diameter of $1.32 \mathrm{~mm}$. At 60 days of growth, the seedlings also did not showed response to rhizobia inoculation, and showed an average diameter of $2.44, \mathrm{~mm}$. On the other hand, at 90 days, the treatment with rhizobia inoculation influenced the diameter. The best responses received from isolates $36 \mathrm{~F}, 43 \mathrm{~K}$ and $45 \mathrm{G}$, that presented shoot diameter of $4.03 ; 4.11$ and $4.02 \mathrm{~mm}$, respectively, similar to the treatment with mineral nitrogen.

\section{Nodulation and root biomass of Leucaena leucocephala}

The plants of Leucaena leucocephala showed an average of 23 nodules, indicating no difference to the treatment without rhizobia inoculation (Table 2). The nodules biomass was influenced by the treatment with rhizobia inoculation, and the isolate $45 \mathrm{G}$ provided the highest biomass $(47 \mathrm{mg}$ plant $^{-1}$ ). No significant differences were observed in the dry matter of roots, suggesting that the isolates did not influence the root growth of Leucaena leucocephala. The dry matter of roots showed an average of 2.29 g plant $^{-1}$ (Table 2).

\section{$N$ accumulation and symbiotic efficiency}

The effect of inoculation was not observed on the nitrogen contents in the aerial biomass of the two legumes. However, due to the great difference in the shoot biomass, there was a significant effect on the total $\mathrm{N}$ accumulation of nitrogen in shoots (Table 3), especially when inoculated with the isolates $36 \mathrm{~F}$ and $45 \mathrm{G}$. These results showed the effectiveness of FBN that was higher than $90 \%$, and did not differ to the treatments with mineral nitrogen. Positive and significant correlations were obtained with the highest correlation coefficients obtained from shoot dry matter and total nitrogen accumulated in the shoots (Table 4).

\section{Discussion}

The height and diameter of plants have been recently used for evaluation of symbiotic efficiency of rhizobia in tree legumes (Ceccon et al., 2012; Ramos et al., 2013; Primieri et al., 2016; Menezes et al., 2017). These parameters indicate the quality of the seedlings, the potential of survival and growth after transplanting. There are usually more vigorous and resistant plants in the field and due to these characteristics (Caione et al., 2012).

In the present study, we verified that the inoculation practice allowed the plants to obtain greater growth in height and diameter, compared to non-inoculated plants (control), or those contained rhizobia but did not receive $\mathrm{N}$ fertilizer. However, significant contrasts were only observed in the results obtained at 90 days of growth. The absence of significant differences in the first two evaluations may be correlated with the time needed to establish the symbiosis. Normally, some tree legumes require 20 to 30 days to show evidence of root nodules, and this fact delayed the BNF process (Mendes et al., 2013).

The existence of compatible native rhizobia populations was demonstrated by the natural nodulation in the not inoculated soils. The rhizobia population varied in size according to the soil which evidenced the differences in nodulation between the treatments. Many studies have shown that nodulation is affected by several factors such as type of specific rhizobia bacteria and the climatic conditions (Lira Junior et al., 2015). The symbiosis cannot be established in the absence of native rhizobia populations capable to nodulate certain legume species. Generally, populations of rhizobia capable of nodulation the specific native legumes are abundant in soils of regions, where the species are native (Bala et al., 2003). However, $L$. leucocephala is an exotic legume species, native to Central America, and yet has nodulation in all soils, possibly due to the high promiscuity of this species, which is able to establish symbiosis with rhizobia of the genus Rhizobium (Pereyra et al., 2015), Mesorhizobium (Rangel et al., 2016), Sinorhizobium (Xu et al., 2014), Bradyrhizobium (Wang et al., 2006), and Cupriavidus (Florentino et al., 2009),

Inoculation with native isolates of Rhizobia has significantly increased shoot biomass and symbiotic effectiveness compared to the recommended and noninoculated plants. The accumulation of nitrogen in shoot dry matter is normally used to estimate the symbiotic efficiency of nitrogen fixation of the native rhizobia according to Lima et al. (2012) and Calheiros et al. (2015). This method is easy to use and is relatively inexpensive. It is especially more suitable for use in soils with low nitrogen content (Rondon et al., 2007). The obtained results in our study showed that the native isolates presented symbiotic efficiency and better performance, ranging from 92 to $105 \%$, in accordance with the reported by above mentioned authors. The best performance of native isolates compared with the recommended strains and the commercial inoculants has been reported in the literature (Calheiros et al., 2015) with calopogonium species, using isolates native to Northeast Brazil (84 to 131\%). Menezes et al. (2017) reported the 
Table 1. Height and diameter of L. leucocephala seedlings grown in pots with the different soils in response to rhizobia inoculation at 30,60 and 90 days after planting date.

\begin{tabular}{llll}
\hline & & Days after planting date & \\
Isolates & 30 & 60 & 90 \\
\hline & Plant height $(\mathrm{cm})$ & & $47.0^{\mathrm{b}} \pm 17.9$ \\
36F & $15.4^{\mathrm{a}} \pm 3.7$ & $27.5^{\mathrm{a}} \pm 7.6$ & $57.2^{\mathrm{a}} \pm 9.1$ \\
$43 \mathrm{~K}$ & $14.1^{\mathrm{a}} \pm 3.0$ & $29.6^{\mathrm{a}} \pm 6.3$ & $47.8^{\mathrm{b}} \pm 11.1$ \\
$45 \mathrm{G}$ & $14.3^{\mathrm{a}} \pm 3.6$ & $26.2^{\mathrm{a}} \pm 6.5$ & $52.6^{\mathrm{a}} \pm 9.2$ \\
SEMIA 6069 & $15.5^{\mathrm{a}} \pm 3.7$ & $31.4^{\mathrm{a}} \pm 5.7$ & $45.6^{\mathrm{b}} \pm 10.9$ \\
N mineral fertilizer & $15.3^{\mathrm{a}} \pm 2.2$ & $28.8^{\mathrm{a}} \pm 4.9$ & $47.8^{\mathrm{b}} \pm 15.3$ \\
Control without N & $15.7 \mathrm{a} \pm 3.3$ & $29.3^{\mathrm{a}} \pm 4.4$ & $42.7^{\mathrm{b}} \pm 6.7$ \\
\hline Average & $14.2^{\mathrm{a}} \pm 1.3$ & $24.6^{\mathrm{a}} \pm 2.3$ & 47.2 \\
CV (\%) & 14.9 & 28.2 & 14.6 \\
\hline & 12.8 & 18.16 & $3.44^{\mathrm{b}} \pm 0.17$ \\
$25 \mathrm{~A}$ & Plant diameter $(\mathrm{mm})$ & & $4.03^{\mathrm{a}} \pm 0.18$ \\
$36 \mathrm{~F}$ & $1.21^{\mathrm{a}} \pm 0.11$ & $2.25^{\mathrm{a}} \pm 0.18$ & $4.11^{\mathrm{a}} \pm 0.55$ \\
$43 \mathrm{~K}$ & $1.32^{\mathrm{a}} \pm 0.06$ & $2.42^{\mathrm{a}} \pm 0.12$ & $4.02^{\mathrm{a}} \pm 0.17$ \\
$45 \mathrm{G}$ & $1.36^{\mathrm{a}} \pm 0.10$ & $2.45^{\mathrm{a}} \pm 0.17$ & $3.36^{\mathrm{b}} \pm 0.12$ \\
SEMIA 6069 & $1.29 \mathrm{a} \pm 0.13$ & $2.55^{\mathrm{a}} \pm 0.23$ & $4.01^{\mathrm{a}} \pm 0.43$ \\
$\mathrm{~N}$ mineral fertilizer & $1.34 \mathrm{a} \pm 0.04$ & $2.44^{\mathrm{a}} \pm 0.09$ & $3.64^{\mathrm{b}} \pm 0.14$ \\
Control without N & $1.34^{\mathrm{a}} \pm 0.15$ & $2.62^{\mathrm{a}} \pm 0.12$ & 3.79 \\
\hline Average & $1.37^{\mathrm{a}} \pm 0.15$ & $2.39^{\mathrm{a}} \pm 0.07$ & 7.85 \\
CV (\%) & 1.32 & 2.44 & \\
\hline
\end{tabular}

*Data with the same letter are not significantly different for Scott-Knott $(p<0.05)$.

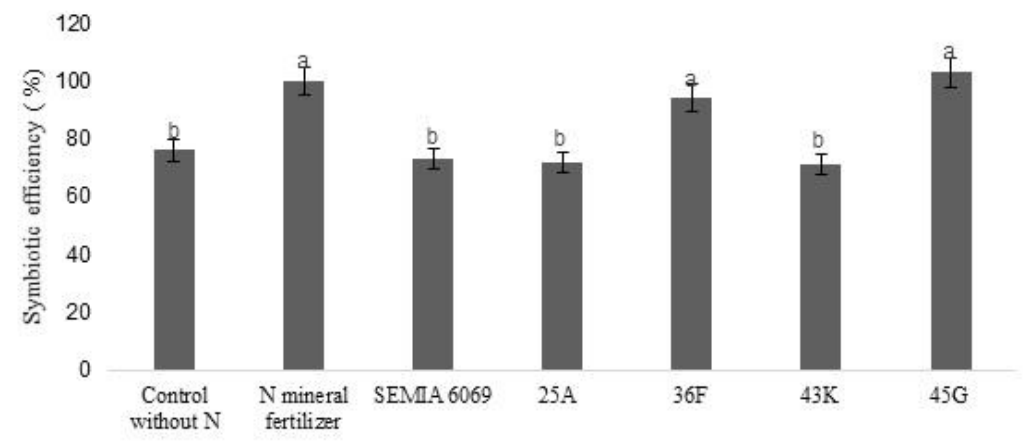

Fig 1. Relative effectiveness of the rhizobia native. The means were compared by the Scott-Knott test $(p<0.05)$.

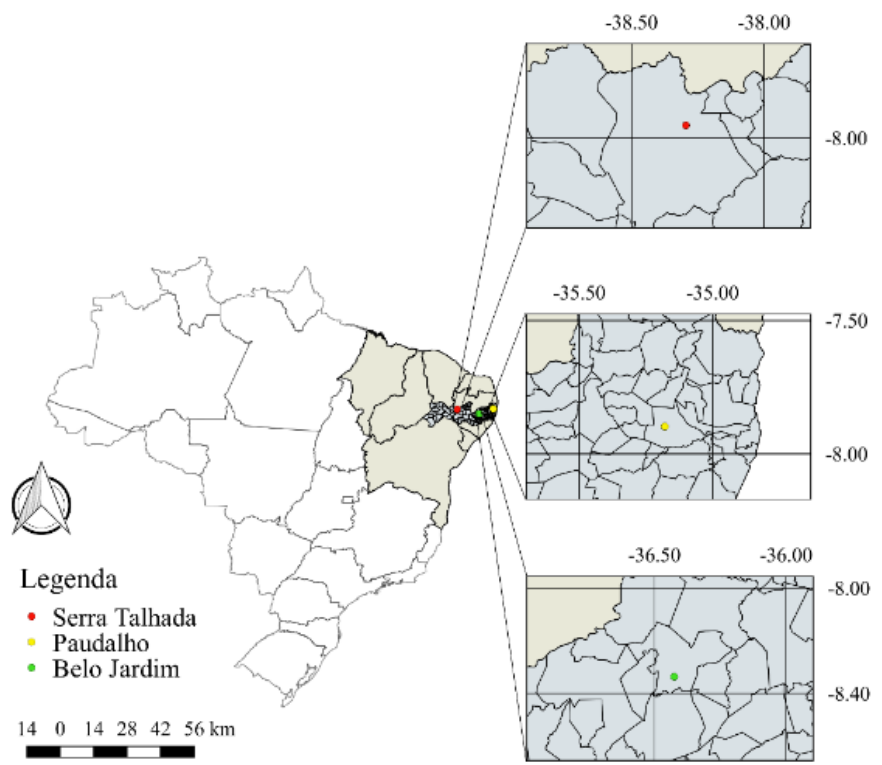

Fig 2. Localities where are collected the soil samples used in the greenhouse experiments 
Table 2. Nodules number, dry biomass of nodules of L. leucocephala grown in different soils (Ultisol, Oxisol and Luvisol) from Brazilian Northeast, in function of rhizobia inoculation.

\begin{tabular}{|c|c|c|c|c|c|c|c|c|}
\hline \multirow{3}{*}{ Isolate } & \multicolumn{3}{|c|}{ Soil class } & \multicolumn{5}{|c|}{ Soil class } \\
\hline & Ultisol & Oxisol & Luvisol & average & Ultisol & Oxisol & Luvisol & average \\
\hline & \multicolumn{4}{|c|}{-------Number of nodules ------------ } & \multicolumn{4}{|c|}{--- Dry biomass of nodules (mg plant ${ }^{-1}$ ) } \\
\hline $25 \mathrm{~A}$ & $21^{A_{a}} \pm 15$ & $36^{A_{a}} \pm 18$ & $11^{A} \underline{a} \pm 5$ & $23 a \pm 12$ & $39^{A} \underline{a} \pm 13$ & $35^{A} \underline{a} \pm 12$ & $37^{A} \underline{a} \pm 15$ & $37^{b} \pm 02$ \\
\hline $36 \mathrm{~F}$ & $18^{A} \underline{a} \pm 9$ & $33^{A_{a}} \pm 14$ & $12^{A} \underline{a} \pm 6$ & 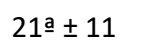 & $27^{A_{a}} \pm 05$ & $36^{A} \underline{a} \pm 08$ & $33^{A} \underline{a} \pm 08$ & $32^{\mathrm{b}} \pm 04$ \\
\hline $43 \mathrm{~K}$ & $26^{A} \underline{a} \pm 13$ & $33^{A_{a}} \pm 31$ & $13^{A} \underline{a} \pm 7$ & $24 \underline{a} \pm 10$ & $33^{A} \underline{a} \pm 12$ & $42^{A} \underline{a} \pm 26$ & $19^{A} \underline{a} \pm 18$ & $31^{b} \pm 12$ \\
\hline $45 G$ & $31^{A} \underline{a} \pm 08$ & $42^{A} \underline{a} \pm 18$ & $16^{A_{a}} \pm 2$ & $30 \mathrm{a} \pm 13$ & $55^{A} \underline{a} \pm 06$ & $38^{A} \underline{a} \pm 12$ & $47^{A} \underline{a} \pm 03$ & $47^{\mathrm{a}} \pm 09$ \\
\hline SEMIA 6069 & $26^{A} a \pm 10$ & $27^{A} \underline{a} \pm 18$ & $14^{A} \underline{a} \pm 3$ & $222^{a} \pm 8$ & $38^{A} \underline{a} \pm 04$ & $39^{A} \underline{a} \pm 08$ & $21^{A} \underline{a} \pm 3$ & $33^{b} \pm 10$ \\
\hline $\mathrm{N}$ mineral fertilizer & $21^{A} \underline{a} \pm 14$ & $20^{A} \underline{a} \pm 15$ & $10^{A} \underline{a} \pm 14$ & $17 \underline{a} \pm 6$ & $29^{A} \underline{a} \pm 16$ & $26^{A} \underline{a} \pm 13$ & $11^{A} \underline{a} \pm 10$ & $22^{b} \pm 10$ \\
\hline Control without $\mathrm{N}$ & $24^{A} \underline{a} \pm 9$ & $30^{A} \underline{a} \pm 7$ & $26^{A} \underline{a} \pm 7$ & $27 a \pm 3$ & $30^{A} \underline{a} \pm 13$ & $39^{A} \underline{a} \pm 11$ & $35^{A} \underline{a} \pm 13$ & $35^{a} \pm 5$ \\
\hline Average & $24 \mathrm{~A} \pm 4$ & $32 \mathrm{~A} \pm 7$ & $14 B \pm 5$ & 23 & $32 \mathrm{~A} \pm 10$ & $34 \mathrm{~A} \pm 05$ & $36 \mathrm{~A} \pm 13$ & 34 \\
\hline \multirow[t]{2}{*}{ CV (\%) } & 30.78 & & & & 35.16 & & & \\
\hline & \multicolumn{4}{|c|}{ Biomass of roots (g plant ${ }^{-1}$ ) } & \multicolumn{4}{|c|}{ Biomass of shoots (g plant ${ }^{-1}$ ) } \\
\hline $25 \mathrm{~A}$ & $2.8^{A} \pm 0.5$ & $2.0^{A_{a}} \pm 0.3$ & $2.6^{A_{a}} \pm 0.4$ & $2.4 \mathrm{a} \pm 0.2$ & $2.8^{\mathrm{bA}} \pm 0.4$ & $2,0^{\mathrm{bA}} \pm 0.3$ & $2,6^{\mathrm{bA}} \pm 0.3$ & $2,5^{b} \pm 0.4$ \\
\hline $36 \mathrm{~F}$ & $2.6^{A_{a}} \pm 0.5$ & $2.2^{\mathrm{A} a} \pm 0.5$ & $2,6^{\mathrm{A}} \underline{\underline{a}} \pm 0.7$ & $2.5^{\mathrm{a}} \pm 0.2$ & $3.7^{\mathrm{aA}} \pm 0.3$ & $2.7^{\mathrm{aB}} \pm 0.4$ & $3.1^{\mathrm{aB}} \pm 0.1$ & $3.2^{\mathrm{a}} \pm 0.5$ \\
\hline $43 \mathrm{~K}$ & $2.5^{\mathrm{A}} \underline{\underline{a}} \pm 0.2$ & $2.0^{A} \underline{a} \pm 0.1$ & $2.1^{\mathrm{A}} \underline{\underline{a}} \pm 0.1$ & $2.2^{\mathrm{a}} \pm 0.2$ & $2.9^{\mathrm{bA}} \pm 0.2$ & $1.9^{\mathrm{bB}} \pm 0.7$ & $2.5^{\mathrm{bA}} \pm 0.2$ & $2.4^{b} \pm 0.5$ \\
\hline $45 G$ & $2.9^{\mathrm{A}} \underline{a} \pm 0.5$ & $2.1^{A_{a}} \pm 0.7$ & $2.3^{\mathrm{A}} \underline{a} \pm 0.9$ & $2.4^{\mathrm{a}} \pm 0.4$ & $3.8^{\mathrm{aA}} \pm 1.0$ & $3.3^{\mathrm{aA}} \pm 0.5$ & $3.7^{\mathrm{aA}} \pm 0.2$ & $3.6^{a} \pm 0.3$ \\
\hline SEMIA 6069 & $3.3^{A} \underline{a} \pm 0,5$ & $1.8^{A} \underline{a} \pm 0.2$ & $1.9^{\mathrm{A}} \underline{a} \pm 0.8$ & $2.3^{a} \pm 0.8$ & $2.7^{\mathrm{bA}} \pm 0.5$ & $2.4^{\mathrm{bA}} \pm 0.3$ & $2.5^{\mathrm{bA}} \pm 0.4$ & $2.5^{b} \pm 0.2$ \\
\hline $\mathrm{N}$ mineral fertilizer & $2.4^{A_{a}} \pm 0.6$ & $1.9^{A} \underline{a} \pm 0.4$ & $1.8^{\mathrm{A}} \underline{a} \pm 0.1$ & $2.0^{\mathrm{a}} \pm 0.3$ & $3.9^{\mathrm{aA}} \pm 0.3$ & $3.0^{\mathrm{aB}} \pm 0.3$ & $3.6^{\mathrm{aA}} \pm 0.3$ & $3.5^{\mathrm{a}} \pm 0.4$ \\
\hline Control without N & $2.9^{\mathrm{A}} \underline{a} \pm 0.1$ & $2.0^{A} \underline{a} \pm 0.4$ & $1.4^{\mathrm{A}} \underline{a} \pm 0.7$ & $2.1^{a} \pm 0.8$ & $2.9^{\mathrm{bA}} \pm 0.4$ & $2.1^{\mathrm{bA}} \pm 0.2$ & $2.7^{\mathrm{bA}} \pm 0.4$ & $2.6^{b} \pm 0.4$ \\
\hline Average & $2.7^{A} \pm 0.3$ & $2.0^{A} \pm 0.14$ & $2.1^{\mathrm{A}} \pm 0.4$ & 2.3 & $3.3^{A} \pm 0.5$ & $2.5^{C} \pm 0.5$ & $2.9^{B} \pm 0.5$ & 2.9 \\
\hline CV (\%) & 22.08 & & & & 14.56 & & & \\
\hline
\end{tabular}

Data with same letter are not significantly different (capital letters compare the soils), and (low letters compare the fertilization treatments) for Scott-Knott ( $\mathrm{p}<0.05)$. 
Table 3. Concentration and total $\mathrm{N}$ accumulation in shoot dry biomass of L. leucocephala grown in different soils (Ultisol, Oxisol and Luvisol) from Brazilian Northeast, in function of rhizobia inoculation.

\begin{tabular}{|c|c|c|c|c|}
\hline \multirow{3}{*}{ Isolate } & \multicolumn{3}{|c|}{ Soil class } & \multirow{3}{*}{ Average } \\
\hline & Ultisol & Oxisol & Luvisol & \\
\hline & \multicolumn{3}{|c|}{ Concentration $\mathrm{N}$ in shoot dry matter (dag kg $\left.{ }^{-1}\right)$} & \\
\hline $25 \mathrm{~A}$ & $1.9^{A} \underline{a} \pm 0.1$ & $1.9^{\mathrm{A}_{\mathrm{a}}} \pm 0.1$ & $1.9^{A} \underline{a} \pm 0.2$ & $1.9 a \pm 0.1$ \\
\hline $36 \mathrm{~F}$ & $1.9^{\mathrm{A}} \underline{a} \pm 0.2$ & $2.0^{A} \underline{a} \pm 0.2$ & $1.7^{A} \underline{a} \pm 0.1$ & $1.9 a \pm 0.1$ \\
\hline $43 \mathrm{~K}$ & $2.0^{A} \underline{a} \pm 0.1$ & $1.7^{A} \underline{a} \pm 0.1$ & $1.9^{A} \underline{a} \pm 0.1$ & $1.8 \mathrm{a} \pm 0.1$ \\
\hline $45 G$ & $1.8^{\mathrm{A} a} \pm 0.2$ & $1.8^{A_{a}} \pm 0.2$ & $1.8^{\mathrm{A} a} \pm 0.1$ & $1.8 \pm 0.1$ \\
\hline SEMIA 6069 & $1.9^{A} \underline{a} \pm 0.1$ & $1.8^{\mathrm{A}} \underline{a} \pm 1$ & $1.9^{\mathrm{A}} \underline{a} \pm 0.1$ & $1.8 \pm 0.1$ \\
\hline $\mathrm{N}$ mineral fertilizer & $1.9^{A} \underline{a} \pm 0.1$ & $1.8^{\mathrm{A}} \underline{a} \pm 0.2$ & $1.8^{A} \underline{a} \pm 0.2$ & $1.8 \pm 0.1$ \\
\hline Control without $\mathrm{N}$ & $1.9^{\mathrm{A}} \underline{a} \pm 0.2$ & $1.8^{A} \underline{a} \pm 0.1$ & $2.0^{\mathrm{A}} \underline{\mathrm{a}} \pm 0.1$ & $1.9 a \pm 0.1$ \\
\hline Average & $1.9^{\mathrm{A}} \pm 0.1$ & $1.8^{\mathrm{A}} \pm 0.1$ & $1.8^{\mathrm{A}} \pm 0.1$ & 1.9 \\
\hline \multirow[t]{2}{*}{ CV (\%) } & \multicolumn{4}{|c|}{8.6} \\
\hline & \multicolumn{4}{|c|}{ Total $\mathrm{N}$ accumulated in shoot dry matter $\left(\mathrm{mg} \mathrm{plant}^{-1}\right)$} \\
\hline $25 \mathrm{~A}$ & $54^{A} \underline{a} \pm 7$ & $38^{A} \underline{a} \pm 4$ & $47^{A} \underline{a} \pm 6$ & $46^{b} \pm 8$ \\
\hline $36 \mathrm{~F}$ & $71^{A} \pm \pm 8$ & $54^{\mathrm{A}} \underline{a} \pm 7$ & $55^{\mathrm{A} a} \pm 3$ & $60^{a} \pm 10$ \\
\hline $43 \mathrm{~K}$ & $59^{A} a \pm 3$ & $33^{A} \underline{a} \pm 11$ & $46^{A} \underline{a} \pm 5$ & $46^{b} \pm 13$ \\
\hline $45 G$ & $70^{A} \underline{a} \pm 28$ & $60^{A} \underline{a} \pm 9$ & $64^{\mathrm{A}} \underline{a} \pm 3$ & $65^{a} \pm 5$ \\
\hline SEMIA 6069 & $49^{A} \underline{a} \pm 14$ & $42^{\mathrm{A}} \underline{a} \pm 4$ & $47^{A} \underline{a} \pm 9$ & $46^{\mathrm{b}} \pm 4$ \\
\hline $\mathrm{N}$ mineral fertilizer & $73^{\mathrm{A}} \underline{a} \pm 8$ & $55^{\mathrm{A} a} \pm 7$ & $64^{A} \underline{a} \pm 2$ & $64^{a} \pm 9$ \\
\hline Control without N & $57^{A} \underline{a} \pm 3$ & $37^{A} \underline{a} \pm 5$ & $53^{A} \underline{a} \pm 10$ & $49^{b} \pm 10$ \\
\hline Average & $62.2^{A} \pm 9$ & $46^{c} \pm 11$ & $54.3^{B} \pm 8$ & 54 \\
\hline CV (\%) & \multicolumn{4}{|c|}{17.02} \\
\hline
\end{tabular}

Data with same letter are not significantly different (capital letters compare the soils), and (low letters compare the fertilization treatments) for Scott-Knott $(\mathrm{p}<0.05)$.

Table 4. Correlation between growth parameters in the two tree legumes

\begin{tabular}{|c|c|c|c|c|c|c|c|c|}
\hline Variables & Diameter & $\begin{array}{l}\text { Number of } \\
\text { nodules }\end{array}$ & $\begin{array}{l}\text { Biomass of } \\
\text { nodules }\end{array}$ & $\begin{array}{l}\text { Biomass of } \\
\text { shoots }\end{array}$ & $\begin{array}{l}\text { Biomass of } \\
\text { roots }\end{array}$ & $\begin{array}{l}\mathrm{N} \text { in } \\
\text { shoot }\end{array}$ & $\begin{array}{l}\mathrm{N} \\
\text { accumulated }\end{array}$ & $\begin{array}{l}\text { Symbiotic } \\
\text { efficiency }\end{array}$ \\
\hline & Leucena & & & & & & & \\
\hline Height & $0.583^{*}$ & $0.058^{\mathrm{ns}}$ & $0.300^{*}$ & $0.669^{*}$ & $0.240^{\mathrm{ns}}$ & $-0.048^{\mathrm{ns}}$ & $0.623^{*}$ & $0.359 *$ \\
\hline Diameter & & $0.016^{\mathrm{ns}}$ & $0.085^{\mathrm{ns}}$ & $0.637^{*}$ & $0.164^{\mathrm{ns}}$ & $-0.060^{\mathrm{ns}}$ & $0.584^{*}$ & $0.427^{*}$ \\
\hline Number of nodules & & & $0.701^{*}$ & $0.149^{\mathrm{ns}}$ & $-0.233^{n s}$ & $-0.105^{\mathrm{ns}}$ & $0.111^{\mathrm{ns}}$ & $0.292 *$ \\
\hline Biomass of nodules & & & & $0.263^{*}$ & $-0.031^{n s}$ & $-0.225^{\mathrm{ns}}$ & $0.187^{\mathrm{ns}}$ & $0.261 *$ \\
\hline Biomass of shoots & & & & & $0.012^{\mathrm{ns}}$ & $-0.064^{\mathrm{ns}}$ & $0.935^{*}$ & $0.789 *$ \\
\hline Biomass of roots & & & & & & -0.050 & $-0.028^{n s}$ & $-0.069^{\mathrm{ns}}$ \\
\hline $\mathrm{N}$ in shoot & & & & & & & $0.285^{*}$ & $0.189^{\mathrm{ns}}$ \\
\hline $\mathrm{N}$ accumulated & & & & & & & & $0.820^{*}$ \\
\hline
\end{tabular}

the highest competitive potential among several rhizobia isolates by Erythrina velutina, which is native to Brazilian semiarid regions compared to the recommended strain. They observed a very positive effectiveness of the native rhizobia.

Based on the interval used by Lalande et al. (1990), it was evident from our study that the native isolates were highly efficient (> 80\%) in effectiveness of biological nitrogen fixation. These results demonstrate the possibility of selecting strains of native rhizobia within the natural diversity, highly adapted to the Brazilian Semiarid region. These native rhizobia are able to establish effective symbiosis. The selection of such isolates is essential for the inoculation of tree legumes because they contribute to increase the amount of fixable $\mathrm{N}_{2}$. It is very important practice to $\mathrm{N}$ enrichment in places where the soils have low total $\mathrm{N}$ content and organic matter. Normally, in these areas the use of mineral fertilizer is inaccessible to most farmers.

\section{Materials and methods}

\section{Experimental conditions}

The greenhouse experiment was conducted for evaluation of symbiotic efficiency of native rhizobia on growth of tree legume Leucaena leucocephala in Brazilian Semiarid soils. The native rhizobia were isolated from nodules of $L$. leucocephala grown in various Brazilian Semiarid soils (Silva et al. 2016). In the present experiment, the seedlings of $L$. leucocephala were grown in pots $\left(2 \mathrm{dm}^{-3}\right)$ using superficial layer $(0-20 \mathrm{~cm})$ of the Brazilian Northeast, collecting soils of different classes (Luvisol, Ultisol and Oxisol) from agricultural areas (Fig 2). The soil samples were air dried, sieved (to $5 \mathrm{~mm}$ ) and applied to the relative pots. In order to preserve the original conditions of the soils, no limestone (for acidity correction) and fertilizer (as nutrient) was added. 
Table 5. Attributes of the soil and characteristics of the sites of samples collection.

\begin{tabular}{|c|c|c|c|}
\hline \multirow[b]{2}{*}{ Characteristics } & \multicolumn{3}{|c|}{ Soil Classes } \\
\hline & Luvisol & Ultisol & Oxisol \\
\hline $\mathrm{pH}\left(\mathrm{H}_{2} \mathrm{O}\right)$ & $6.76 \pm 0.12$ & $6.28 \pm 0.29$ & $5.56 \pm 0.32$ \\
\hline Total C $\left(\mathrm{g} \mathrm{kg}^{-1}\right)$ & $7.7 \pm 2.4$ & $8.4 \pm 0.9$ & $3.0 \pm 0.5$ \\
\hline Available $\mathrm{P}\left(\mathrm{mg} \mathrm{dm}^{3}\right)$ & $106 \pm 13.8$ & $69 \pm 11.7$ & $8 \pm 2.2$ \\
\hline Available $\mathrm{K}^{+}$ & $292 \pm 58$ & $284 \pm 42$ & $135 \pm 7.5$ \\
\hline Exchangeable $\mathrm{Ca}^{2+}\left(\mathrm{cmol}_{\mathrm{c}} \mathrm{dm}^{3}\right)$ & $2.85 \pm 0.19$ & $2.04 \pm 0.92$ & $1.34 \pm 7.5$ \\
\hline Exchangeable $\mathrm{Mg}^{2+}\left(\mathrm{cmol}_{\mathrm{c}} \mathrm{dm}^{3}\right)$ & $0.86 \pm 0.23$ & $0.89 \pm 0.21$ & $0.58 \pm 0.12$ \\
\hline Exchangeable $\mathrm{Al}^{3+}\left(\mathrm{cmol}_{\mathrm{c}} \mathrm{dm}^{3}\right)$ & $0.0 \pm 0.0$ & $0.0 \pm 0.0$ & $0.11 \pm 0.03$ \\
\hline $\mathrm{H}+\mathrm{Al}\left(\mathrm{cmol}_{\mathrm{c}} \mathrm{dm}^{3}\right)$ & $2.15 \pm 0.47$ & $2.70 \pm 0.63$ & $2.91 \pm 0.15$ \\
\hline Soil Density SD $\left(\mathrm{g} \mathrm{cm}^{3}\right)$ & $1.61 \pm 0.04$ & $1.55 \pm 0.01$ & $1.31 \pm 0.07$ \\
\hline Particles density $\mathrm{Dp}\left(\mathrm{g} \mathrm{cm}^{3}\right)$ & $2.60 \pm 0.03$ & $2.64 \pm 0.31$ & $2.62 \pm 0.22$ \\
\hline Sand $\left(\mathrm{g} \mathrm{kg}^{-1}\right)$ & $772 \pm 25$ & $713 \pm 18$ & $525 \pm 25$ \\
\hline Silt $\left(\mathrm{g} \mathrm{kg}^{-1}\right)$ & $71 \pm 23$ & $98 \pm 11$ & $103 \pm 10$ \\
\hline Clay $\left(\mathrm{g} \mathrm{kg}^{-1}\right)$ & $137 \pm 5$ & $189 \pm 7$ & $372 \pm 19$ \\
\hline Site of sample collection & Serra Talhada & Belo Jardim & Paudalho \\
\hline Altitude $(\mathrm{m})$ & 429 & 608 & 86 \\
\hline Annual Rainfall (mm) & 716 & 660 & 1239 \\
\hline Temperature & 24 & 24 & 25 \\
\hline
\end{tabular}

Table 6. Phenotypic characteristics of L. leucocephala rhizobia isolated from Brazilian Semiarid soils.

\begin{tabular}{|c|c|c|c|c|c|}
\hline \multirow{2}{*}{ Isolates } & \multirow[t]{2}{*}{ Soil } & \multirow{2}{*}{ Land use system } & \multicolumn{2}{|c|}{ Phenotypic characteristic* } & \multirow[b]{2}{*}{ Color } \\
\hline & & & TC & $\mathrm{pH}$ & \\
\hline \multicolumn{6}{|c|}{ Isolates of nodules of Leucaena leucocephala (Leucena) } \\
\hline 25B (Ensifer) & Luvisol & Caatinga & Fast & Acid & Cream \\
\hline 36F (Rhizobium) & Ultisol & Agriculture & Fast & Acid & Cream \\
\hline 43K (Ensifer) & Luvisol & Caatinga & Fast & Acid & Cream \\
\hline 45G (Mesorhizobium) & Luvisol & Agriculture & Fast & Acid & Cream \\
\hline
\end{tabular}

* Growth period; $\mathrm{pH}$ modification in culture (YMA medium) and color of the colony.

The samples were submitted to analyses (Donagema et al., 2011) and the results are shown in Table 5. Seeds of the $L$. leucocephala were mechanically scarified and subsequently disinfested in $70 \%$ alcohol $(1 \mathrm{~min}$ ) and $2 \%$ sodium hypochlorite (5 minutes), and then washed with sterilized water. The seeds were sown directly in to the soil pot (4 seeds pot $^{-1}$ ). Ten days after sowing only one seedling were left in each pot. The inoculation was performed according to Menezes et al. (2017), pipetting $1 \mathrm{ml}\left(10^{9} \mathrm{cfu} / \mathrm{ml}\right)$ of the respective rhizobia isolates for seed. The growth of $L$. leucocephala was evaluated by measuring the height and the diameter of the shoots, using a ruler and a digital caliper, respectively. The plants were evaluated at 30,60 and 90 days after sowing, and the harvest was performed at 90 days. The number of nodules and the dry biomass of shoot, roots and nodules were determined after oven drying at 65으 for 72 hours. Shoots nitrogen concentration was measured using Kjeldahl method (Silva, 2009), and the total accumulated $\mathrm{N}$ calculated by multiplying the nitrogen content and the respective biomass. Symbiotic efficiency was determined as previously described by (Calheiros et al., 2015), based on the relation between the total $N$ accumulation in biomass of inoculated plants/noninoculated control plants supplemented with nitrogen, and then converted into a percentage.

\section{Experimental design}

The experiment was conducted in factorial scheme $(7 \times 3)$ using a complete randomized block design, with four replicates for treatment. The fertilization treatments were: (a) four native isolates, obtained from nodules of Leucaena leucocephala grown in Brazilian Semiarid soils; (b) recommended strain for L. leucocephala; (c) control without rhizobia inoculation and without $\mathrm{N}$ fertilization; (d) control without rhizobia but with $\mathrm{N}$ fertilization $\left(100 \mathrm{mg} \mathrm{kg}^{-1}\right)$ as ammonium nitrate. The treatments were applied in the three different soils (Luvisol, Ultisol and Oxisol).

The native rhizobia $L$. leucocephala were screened in previous assays based on their ability to fragment amplification of the symbiotic genes nifH and $\operatorname{nod} \mathrm{C}$, and because they presented greater dry biomass of shoots, in the previous works conducted in sterilized substrate (Silva, 2017). The native isolates were $25 \mathrm{~A}, 36 \mathrm{~F}, 43 \mathrm{~K}$ and $45 \mathrm{G}$. The recommended strain for L. leucocephala was SEMIA 6069 (Bradyrhizobium elkanii). The phenotypic characteristics of native rhizobia are shown in Table 6.

\section{Statistical analysis}

Results of plant height, shoot diameter, dry biomass of shoot, root and nodules, number of nodules, and shoot nitrogen accumulation were submitted to statistical analysis using the Sisvar computational program (Ferreira, 2011). The F-test data of nodules number were transformed to $(x+$ $1)^{1 / 2}$. The means were compared by the Scott-Knott test 
$(p<0.05)$. The correlation coefficients between the studied variables were calculated by Statistica 8.0.

\section{Conclusion}

The rhizobia isolates $36 \mathrm{~F}$ and $45 \mathrm{G}$ showed to be the most effective on the FBN process, and may represent an excellent strategy to increase the amounts of fixed $\mathrm{N}$, especially in sites where the technological systems need to be increased. The results indicate the potential of the rhizobia native strains that are most effective and competitive and may be used to promote good growth of the used tropical tree legumes. The realization of field experiments may be necessary in terms to prove the potential of the rhizobia inoculants produced by native strains.

\section{Acknowledgements}

We thank the Brazilian National Council for Scientific and Technological Development (CNPq), the Coordination for the Improvement of Higher Level Personnel (CAPES), and the Foundation for Science and Technology of the State of Pernambuco (FACEPE) for financial support and scholarships.

\section{References}

Antunes JEL, Gomes RLF, Lopes ACA, Araújo ASF, Lyra MCCP, Figueiredo MDVB (2011) Symbiotic efficiency of rhizobia isolated from nodules of lima bean (Phaseolus lunatus L.). Rev Bras Ci Solo. 35: 751-757.

Bala A, Murphy PJ, Osunde AO, Giller KE (2003) Nodulation of tree legumes and the ecology of their native rhizobial populations in tropical soils. Appl Soil Ecol. 22: 211-223.

Caione G, Lange A, Schoninger EL (2012) Growth of seedlings Schizolobium amazonicum (Huber ex Ducke) on substrate fertilized with nitrogen, phosphorus and potassium. Sci Fores. 40: 213-221.

Calheiros AS, Junior L, Andrade M, Santos MVF, Lyra MCCP (2015) Symbiotic effectiveness and competitiveness of calopo rhizobial isolates in an argissolo vermelho-amarelo under three vegetation covers in the dry forest zone of Pernambuco. Rev Bras Ci Solo. 39: 367-376.

Ceccon E, Almazo AR, Martínezero ER, Toledo I (2012) The effect of inoculation of an indigenous bacteria on the early growth of Acacia farnesiana in a degraded area. Cerne. 18: 49-57.

Donagema GK, Campos DVB, Calderano SB, Teixeira WG, Viana JHM (2011) Manual de métodos de análise de solos. Embrapa Solos, Rio de Janeiro.

Estringana GP, Alonso-Blázquez N, Marques MJ, Bienes R, González-Andrés F, Alegre J (2013) Use of Mediterranean legume shrubs to control soil erosion and runoff in central Spain. A large-plot assessment under natural rainfall conducted during the stages of shrub establishment and subsequent colonization. Catena. 102: 3-12.

Faye A, Sall S, Chotte JL, Lesueur D (2007) Soil biofunctioning under Acacia nilotica var. tomentosa protected forest along the Senegal River. Nutr Cycl Agroecosyst. 79: 35-44.

Ferreira DF (2011) Sisvar: a computer statistical analysis system. Ciênci Agrotec 35: 1039-1042.
Florentino LA, Guimarães AP, Rufini M, Silva KD, Moreira FMDS (2009) Sesbania virgata stimulates the occurrence of its microsymbiont in soils but does not inhibit microsymbionts of other species. Sci Agr. 66: 667-676.

Freitas ADS, Sampaio E, Santos C, Silva A, Carvalho R (2015) Biological nitrogen fixation in the Brazilian Semiarid. Rev Bras Geo Fís. 8: 585-597.

Freitas ADS, Sampaio EVSB, Santos CERS, Fernandes AR (2010) Biological nitrogen fixation in tree legumes of the Brazilian semi-arid caatinga. J Arid Environ. 74: 344-349.

Freitas ADS, Silva TD, Menezes RSC, Sampaio EVSB, Araújo ER, Fraga VDS (2011) Nodulation and nitrogen fixation of caatinga forage species grown in soils of the semiarid area of Paraiba. R Bras Zootec. 40: 1856-1861.

Lalande R, Bigwaneza PC, Antoun H (1990) Symbiotic effectiveness of strains of Rhizobium leguminosarum biovar Phaseoli isolated from soils of Rwanda. Plant Soil. 121: 41-46.

Lima AAD, Fernandes Júnior PI, Passos SR, Paulo FSD, Nosoline SM, Faria SMD, Guerra JG M, Rumjanek NG, Xavier GR (2012) Diversity and symbiotic capacity of bacteria isolated from nodules of two velvet bean species. Rev Bras Ci Solo. 36: 337-348.

Lira Junior MA, Nascimento LRS, Fracetto GGM (2015) Legume-rhizobia signal exchange: promiscuity and environmental effects. Front Microbiol. 5: 1-9.

Martins JCR, Freitas ADS, Menezes RSC, and Sampaio EVSB (2015) Nitrogen symbiotically fixed by cowpea and gliricidia in traditional and agroforestry systems under semiarid conditions. Pesq Agropec Bras. 50: 178-184.

Mendes MMC, Chaves LFC, Pontes Neto TP, Silva JAA, Figueiredo MVB (2013) Seedlings growth and survival of sabia (Mimosa caesalpiniifolia Benth.) inoculated with symbiotic microorganisms in field conditions. Ciênc Flor. 23: 309-320.

Menezes KAS, Escobar IEC, Fraiz ACR, Martins LMV, Fernandes Júnior PI (2017) Genetic Variability and Symbiotic Efficiency of Erythrina velutina Willd. Root Nodule Bacteria from the Semi-Arid Region in Northeastern Brazil. Rev Bras Ci Solo. 41: 1-13.

Pereyra G, Hartmann H, Michalzik B, Ziegler W, Trumbore S (2015) Influence of Rhizobia Inoculation on Biomass Gain and Tissue Nitrogen Content of Leucaena leucocephala Seedlings under Drought. Forests. 6: 3686-3703.

Primieri S, Dalla CM, Stroschein MRD, Stocco P, Santos JCP, Antunes PM (2016) Variability in symbiotic effectiveness of $\mathrm{N}_{2}$ fixing bacteria in Mimosa scabrella. Appl Soil Ecol. 102: 19-25.

Ramos DBP, Souza LAG (2013) Selection of Rhizobia strains for development seedlings of leucaena (Leucaena leucocephala (Lam)De Wit.) in Red-Yellow Ultisol. Rev Bras Agroec. 8(1): 28-39.

Rangel WM, Thijs S, Moreira FMS, Weyens N, Vangronsveld J, Van Hamme JD, Bottos EM, Rineau F (2016) Draft genome sequence of Mesorhizobium sp. UFLA 01-765, a multitolerant, efficient symbiont and plant growthpromoting Strain Isolated from Zn-mining soil using Leucaena leucocephala as a trap plant. Gen Announ. 4: 12.

Rondon MA, Lehmann J, Ramírez J, Hurtado M (2007) Biological nitrogen fixation by common beans (Phaseolus vulgaris L.) increases with bio-char additions. Biol Fertil Soils. 43: 699-708. 
Silva AF, Freitas ADS, Costa TL, Fernandes Júnior PI, Martins LMV, Silva CERS, Sampaio E VSB (2017) Biological nitrogen fixation in tropical dry forests with different legume diversity and abundance. Nutr Cycl Agroecosyst. 107: 1-14.

Silva FCDS (2009) Manual de análises químicas de solos, plantas e fertilizantes. Embrapa Informação Tecnológica; Rio de Janeiro.

Silva VSG (2017) Prospecção de rizóbios de leguminosas arbóreas em solos do Semiárido brasileiro sob diferentes usos da terra. PhD thesis, Universidade Federal Rural de Pernambuco, Brazil.

Silva VSG, Santos CERS, Freitas ADS, Stamford NP, Silva AF, Lyra MCCP (2016) Systems of land use affecting nodulation and growth of tree legumes in different soils of the Brazilian semiarid area. Afr J Agric Res. 11(40): 3966-3974.

Sizenando CIT, Ramos JPC, Fernandes-Junior PI, Lima LM, Freire RMM, Santos RC (2016) Agronomic efficiency of Bradyrhizobium in peanut under different environments in Brazilian Northeast. Afr J Agric Res. 11: 3482-3487.

Souza LQ, Freitas ADS, Sampaio EVSB, Moura PM, Menezes RSC (2012) How much nitrogen is fixed by biological symbiosis in tropical dry forests? Nutr Cycl Agroecosyst. 94: 171-179.

Wang FQ, Wang ET, Zhang YF, Chen WX (2006) Characterization of rhizobia isolated from Albizia spp. in comparison with microsymbionts of Acacia spp. and Leucaena leucocephala grown in China. Syst Appl Microbiol. 29: 502-517.

Xavier GR, Runjanek NG, Santos CERS, Freitas ADS, Silva VSG, Silva AF, Ferreira JS, Stamford NP, Martins LMV, Leite J, Morgado LB, Alcantara RMCM (2017) Agronomic effectiveness of Rhizobia strains on cowpea in two consecutive years. Aust J Crop Sci. 11(09)1154-1160.

Xu K, Zhang XP, Chen YX, Zhou DH (2014) Genetic diversity of the rhizobia isolated from Leucaena leucocephala in Panzhihua City. Microbiol. China. 41: 1132-1145.

Yuan ZQ, Yu KL, Epstein H, Fang C, Li JT, Liu QQ, Gao WJ, Li FM (2016) Effects of legume species introduction on vegetation and soil nutrient development on abandoned croplands in a semi-arid environment on the Loess Plateau, China. Sci Total Environ. 541(1): 692-700. 